\title{
THE TRAVELLING GIRL AND HER HELPFUL SIBLINGS: AN UNNOTICED BOREAL TALE AND THE ATU INDEX
}

\author{
Yuri Berezkin \\ Museum of Anthropology \& Ethnography (Kunstkamera) \\ Russian Academy of Sciences \\ Department of Anthropology \\ European University at St. Petersburg, Russia \\ e-mail: berezkin1@gmail.com
}

\begin{abstract}
After presenting the results of statistical processing of data on the distribution of folklore motifs in Eurasia, the author describes a previously unnoticed tale that is widespread across Northern Asia. The protagonist of the story is a travelling girl who successfully competes with her rival, often a frogwoman. In the beginning, the heroine parts with her brother(s) or sister, taking them for dead or disappeared forever. Later they appear again and demonstrate their supernatural qualities by helping her. Many particular motifs found in the corresponding Siberian narratives have parallels in the New World, though the basic scheme of the plot is not known in America. Unlike the Western and Southern Eurasian and North American oral traditions well systematized by Stith Thompson, Central and Northern Asian traditions were ignored by him and remain severely underrepresented in comparative folklore studies. The tale described in this article is one of the many not registered in international indexes. Limitations of the present-day system of classification of traditional narratives are related to the uncertainty concerning the purpose of their study.
\end{abstract}

Keywords: big data in folklore studies, Finno-Ugric folklore, folklore indexes, Siberian folklore

\section{ADVENTURE AND TRICKSTER MOTIFS IN FOKLORE TEXTS}

Statistical processing of folklore and mythological motifs (i.e., narrative episodes and ideas related to worldview) demonstrate different and independent tendencies of their areal spread in the Old World. The computed motifs belong to several different thematic groups that probably spread in different time periods and under different circumstances. One group includes episodes and images that expose cosmological and etiological ideas. Another group includes 
episodes of adventure and tricks. Inside the latter, three subgroups can be selected. The first one corresponds to situations that are impossible in reality and are usually not comical. Episodes of the second subgroup do not contain supernatural elements and mostly describe swindles, tricks, and other deviant forms of behavior. The protagonists of both subgroups are anthropomorphic. The third subgroup consists mainly of trickster episodes but with zoomorphic protagonists.

These three subgroups of episodes roughly correspond to particular categories of tale types selected by standard folklore indexes based on the ATU (Aarne-Thompson-Uther) system (Aarne \& Thompson 1961; Uther 2004). These are tales of magic, realistic tales (together with tales of the stupid ogre and anecdotes), and animal tales. Uncertain cases are rare and do not influence the statistical tendencies of the distribution of many hundreds of motifs in hundreds of traditions. However, computing the data of ATU turned out to be impossible. The main reason is that the definitions of most of the tale types provided by this index are not unambiguous enough and often merge two and more episodes under one title, despite the fact that such episodes have different areal distribution (Berezkin 2015). This is not surprising because ATU was never conceived to serve a database for statistical operations. Therefore, we had to create our own system of classification for computing the data, i.e., the electronic catalogue of mythology and folklore (Berezkin \& Duvakin n.d.). This catalogue currently includes abstracts of more than 55,000 texts and contains information on the spread of more than 2,500 ideas related to worldview, and narrative episodes across the whole world, from South Africa to Tierra del Fuego.

The "international" tale type system of ATU was created and elaborated using European, Near Eastern, North African, and South Asian folklore materials, while the Siberian and part of the Central Asian data were practically ignored (Aarne \& Thompson 1961; Thompson 1946). The farther away from Europe and the Near East, the lesser number of the tale types that are recognized by ATU are found in traditional narratives, while there appear ever more types that do not have correspondences in ATU. However, the grouping of the narrative units into episodes of adventure (mostly with supernatural elements), trickster episodes with anthropomorphic protagonists, and trickster episodes with zoomorphic protagonists is largely preserved. Only in the New World, the very opposition between zoo- and anthropomorphic actors, as well as between the supernatural and the real, becomes irrelevant (historical legends standing, of course, apart). 


\section{FACTOR ANALYSIS USED FOR COMPUTING THE DATA}

The results of a quantitative approach to folklore data depend not only on the system of classification of the initial material but also on the choice of particular statistical programs. The program that is used here is the so-called factor analysis, which is a way to reduce a contradictory and extremely complex picture (in our case, the distribution of motifs in hundreds of traditions) to a few clear and understandable tendencies.

In digitized form, our world folklore and mythology database is a binary table (it consists of zeros and ones), with lines for traditions and columns for motifs (i.e., images and episodes). Every tradition is characterized mathematically by long strings of zeroes and ones, representing the absence and presence, respectively, of particular motifs. The extent to which any sets of traditions are similar to each other is a function of the degrees of similarity (correlation) between their representative strings. The strings of zeros and ones are considered to form vectors in a high-dimensional space of motifs. One considers this space to be spanned by underlying, hidden factors or components. Applying particular mathematical procedures, we reduce this set of many different tendencies that cannot be grasped by our brain, to a few major tendencies. The latter are represented by the so-called principal components (PC).

The first PC accounts for the largest possible amount of variability in the data - and thus contains the largest amount of information about the differences between traditions. The next PC has the next highest variance (and information about differences) but is uncorrelated with the first PC, i.e., independent from it. Practically, it means that each PC selects a particular group of traditions that contains the most similar sets of motifs, i.e., shares the biggest number of identical narrative episodes. Concurrently, the corresponding PC selects another group of traditions that contains a set of such narrative episodes that are most different from the episodes typical for the first group. Mathematical indexes for traditions of these two groups selected by the corresponding PC are opposite (one negative and another positive).

Only the first two, three or maximum four PCs reveal tendencies that are relevant for all the computed units, in our case for all selected traditions of Eurasia and North Africa. Other PCs reveal similarity/dissimilarity between traditions on the local level. These two, three or four PCs account for a small proportion of the variances - less (sometimes much less) than $20 \%$ of the total. However, exactly this information is of crucial importance for the research. All the rest is related to a great number of different minor (and often chaotic) tendencies produced thanks to exclusive links between particular traditions and their small groups. 
It should be underlined once again that the tendencies in the distribution of particular narrative episodes revealed by different PCs are independent from each other. Each PC reveals its own pattern of the geographical spread of selected traditions based on the similarity/dissimilarity between them. Each such pattern is most probably related to a particular historical process that took place at a particular time.

\section{THE COMPUTING OF AREAL DISTRIBUTION OF FOLKLORE MOTIFS REVEALS THE NORTHERN AND THE SOUTHERN INTERACTION SPHERES IN EURASIA}

When it comes to computing adventure motifs, the implementation of the 3rd PC for examining the areal distribution of motives demonstrates a difference between the forest and tundra zone of Northern Eurasia and the more southern, or better say, southwestern, regions (Fig. 1). Traditions of Northern Eurasia from the Baltic region to the Sea of Japan share a certain amount of common motifs, while southern traditions from Portugal and Morocco to South Asia share another set of common motifs, which is different from the northern one. The northern zone in its western fringe extends up to the Baltic and its weaker margin encompasses Central Europe and Scandinavia. The highest mathematical indexes (above +3.00 ), i.e., the biggest numbers of corresponding motifs, are for the Nanai, Sakha, Russians, Udeghe, and Chukchi, followed by the Buryats, Mansi, Baikal Evenks, Tundra Samoyeds, Lithuanians, Mari, and Bashkirs. The opposite (Mediterranean - South Asian) southern set of motifs is best represented in the Near East and the adjacent areas among the Persians, Turks, Arabs of Syria, Arabs of Egypt, Armenians, Azeris, and Arabs of Iraq (indexes below -2.00).

The East Asian traditions are mostly neutral, i.e., they contain fewer motifs typical for either of the sets or a mixture of both. The southern area largely corresponds to the folklore of the "western civilization" (or "The Folktale from Ireland to India"), as Stith Thompson named it in contrast to "The Folktale among a Primitive People" (Thompson 1946: vii, 14).

The results of the computing of another subgroup of motifs also evidence in favor of the existence of the northern/southern dichotomy in the distribution of folklore motifs in Eurasia - I mean trickster episodes with animal protagonists. Here one of the main PCs (the 2nd PC) again selects the northern interaction sphere that extends from the Baltic to the Pacific with a margin that includes 


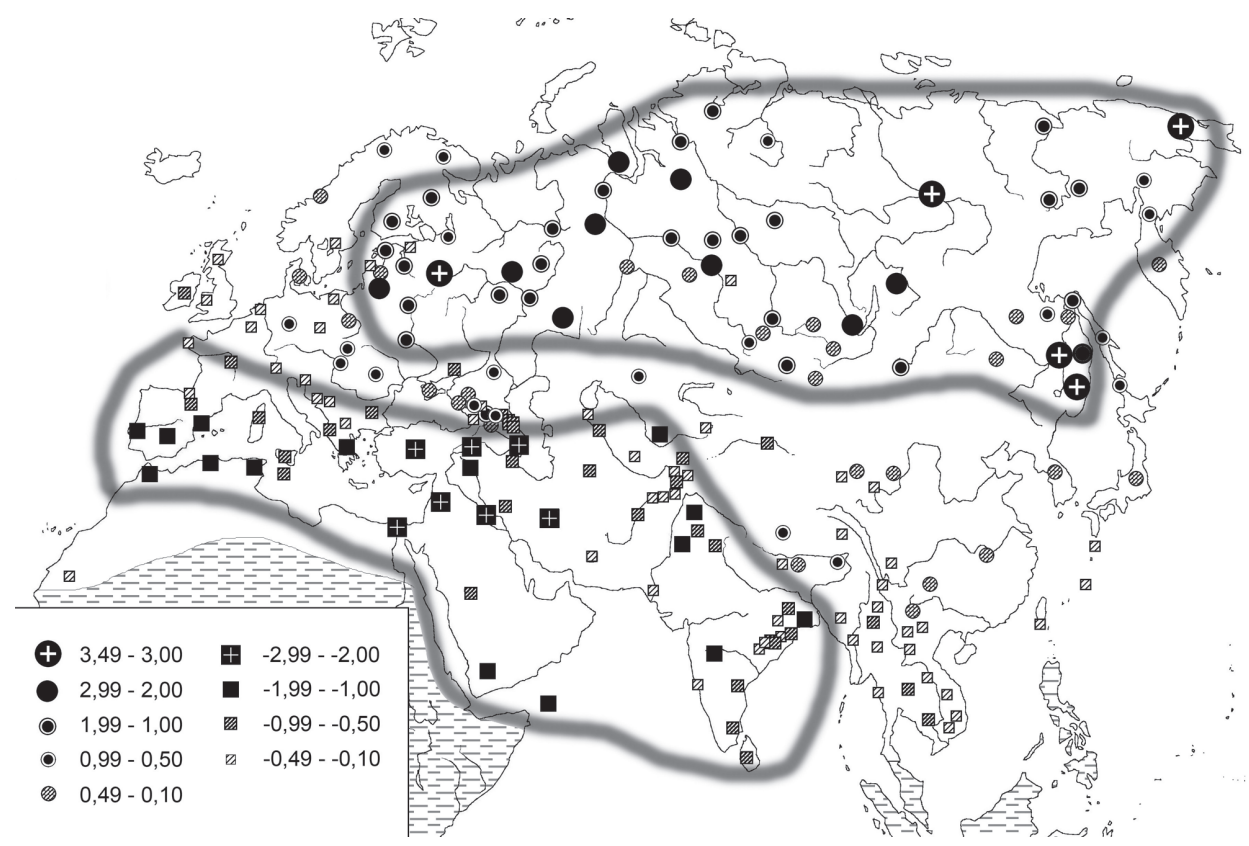

Figure 1. Data on the distribution of 605 episodes of adventure in 290 traditions of Eurasia and Northern Africa, third PC, dispersion (i.e., percent of total information, see explanation in text) 3.0\%. Data from shaded areas (in Africa and Southeast Asia) are not computed. Traditions with mathematical indexes close to zero (from 0.09 to -0.09) are not in the chart (they are neutral in respect to the basic tendencies). Areas with the maximum concentration of motifs typical for the northern and southern (MediterraneanSouth Asian) sets are ringed with a blurred line.

Central Europe, Scotland, and Scandinavia (Fig. 2). The opposite southern zone includes Northern Africa, the Near East, Iran, and South Asia. It does not completely overlap with the southern zone in the distribution of the adventure episodes (Fig. 1), the major difference being the southern and not northern affiliation of the steppe traditions of Central Asia. However, the configuration of the northern (forest and tundra) zone in both cases is very similar. Such a correlation does not happen often and probably means that in Northern Eurasia, episodes of adventure and episodes of animal tales spread because of the same historical circumstances. 


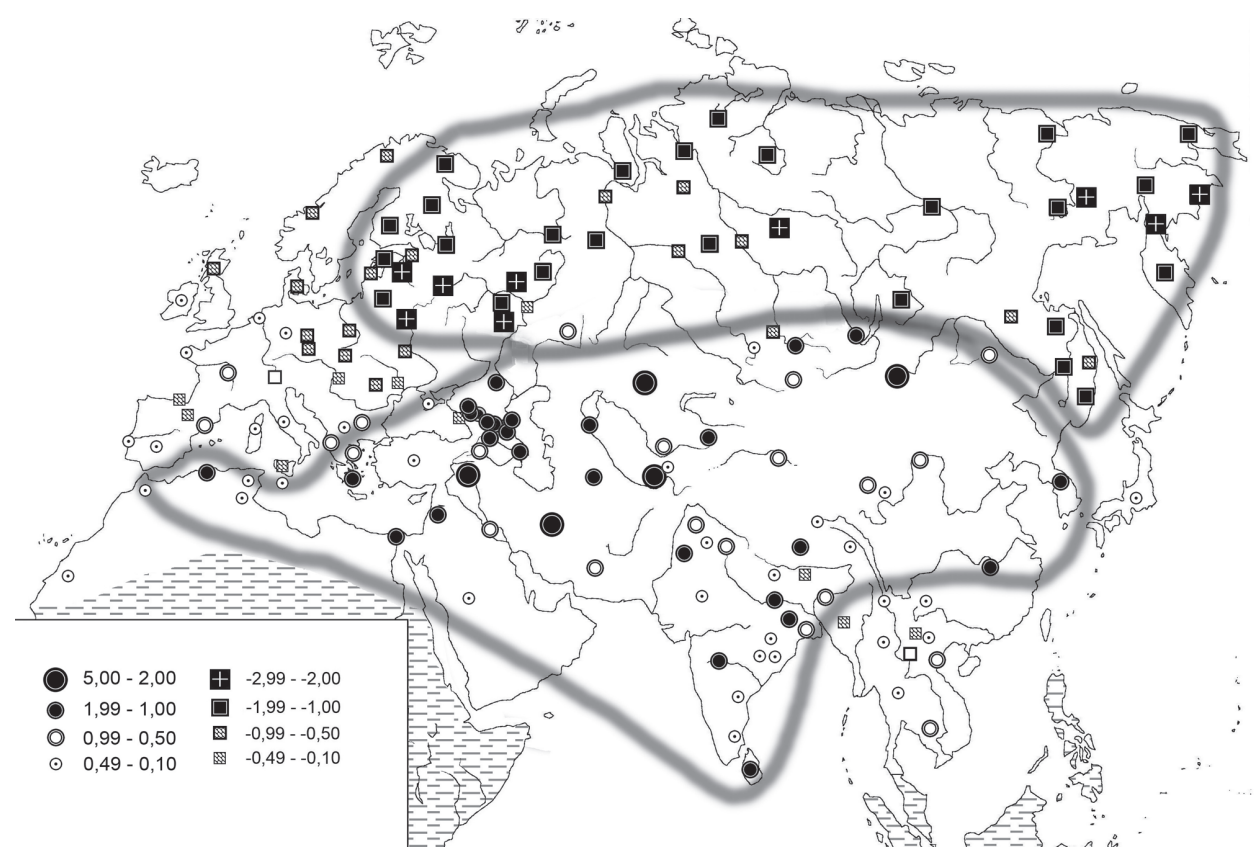

Figure 2. Data on the distribution of 605 episodes of animal tales in 266 traditions of Eurasia and Northern Africa, second PC, dispersion (i.e., percent of total information, see explanation in text) 4.3\%. For other explanations see caption for Figure 1.

\section{STORIES ABOUT THE TRAVELLING GIRL AND HER HELPFUL SIBLINGS}

The series of narratives presented below is one of several tales responsible for the statistical tendencies described above and it has never been selected as a particular analytical unit by scholars. The corresponding narratives provisionally named "The travelling girl and her helpful siblings" have been recorded from Sakhalin to Ural with isolated and only partial analogies in Northeastern Europe from the Middle Volga to the Kola Peninsula (Fig. 3).

The protagonist is a girl opposed to an imposter (often a female frog). The girl has brothers (a brother, a sister) whom she must leave. She takes them for dead or lost forever but later they appear again and help her by demonstrating their supernatural qualities. Another common motif is the marriage of the heroine and the imposter followed by episodes in which the heroine demonstrates her superiority. The particular set of episodes is subject to variations but the 


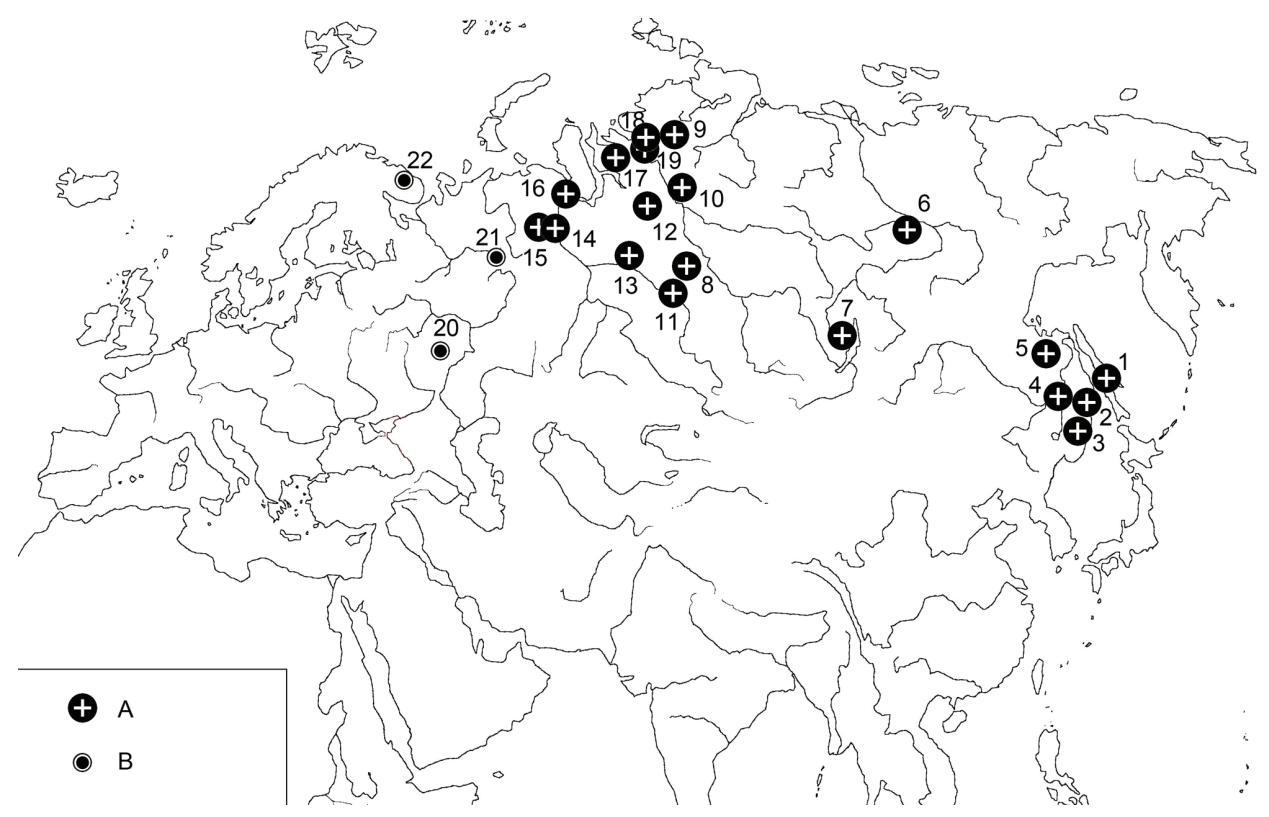

Figure 3. Places where "The travelling girl and her helpful siblings" tale has been recorded. A. Typical (Siberian and Far Eastern) variants. B. European variants. 1. Uilta. 2. Nanai. 3. Oroch. 4. Udeghe. 5. Negidal. 6. Sakha (precise place of recording not specified). 7. Cis-Baikal Evenks. 8. Sym Evenks. 9. Nganasan. 10. Ket. 11. Southern Selkup. 12. Northern Selkup. 13. Eastern Khanty. 14. Northern Khanty. 15. Northern Mansi. 16. Obdorsk Samoyed. 17. Gydan Samoyed. 18. Taimyr Samoyed. B. European variants only partly related to Siberian ones. 19. Komi. 20. Mordvinians. 21. Sami.

common motifs are easily recognized. It should be underlined that the conflict with the imposter does not bring much harm to the heroine. In this respect, the corresponding series of texts are different from such tale types as ATU 403 (The Black and the White Bride), 404 (The Substituted Bride), and other variants in which the heroine is humiliated by her antagonist or even killed.

Partial parallels for North Eurasian texts about the travelling girl or two girls are found in America and across the Asian-Oceanic Pacific rim. However, analogies are completely absent in Africa, across most of Eurasia, in the northeast of Asia, as well as in American Arctic and Subarctic (there is only one distantly related text among the Denaina Athabascans). Such a distribution is typical of motifs brought to America at the (relatively) early stages of its peopling, i.e., before the appearance of the Paleo-Eskimo culture in Alaska (4th millennium BC) (Anderson 2004; Dumond 2005: 28) and probably before the spread of the Paleoasiatic languages in Chukotka and the Na-Dene languages in American Subarctic (Berezkin 2019). 


\section{PARALLELS OF PARTICULAR MOTIFS IN THE SIBERIAN STORIES IN AMERICA}

Many particular motifs of the Siberian "Travelling girl and her helpful siblings" tale, which are used in its different versions, are found among North (and even South) American Indians. It is enough to name but the most obvious parallels. 1. Two women have children, one kills the other and promises to feed her children the meat of the victim's children; the victim's children escape. 2. People shoot arrows, which hit each other's ends and form a chain (rope, ladder) by means of which they climb to the sky (Fig. 4). 3. Being provoked or forced by another, a person slides down a hill and dies or gets into trouble (falls on a sharp pole, into the water, etc.) (Fig. 5). 4. Two sisters or companions are travelling and ultimately get married, one of them being cleverer and more successful than the other. 5. Running away from a dangerous being, a person throws a comb that turns into a thicket, and a whetstone that turns into a mountain (the whetstone is especially worth noticing; Fig. 6). 6. A person stretches his or her leg as a bridge across a water body. 7. A baby boy is thrown into the river but is ultimately lured to the shore and comes to live among people. 8 . The girl and the frog are two daughters-in-law. Subject to a series of tests, one demonstrates her good and the other her bad qualities (Fig. 7).

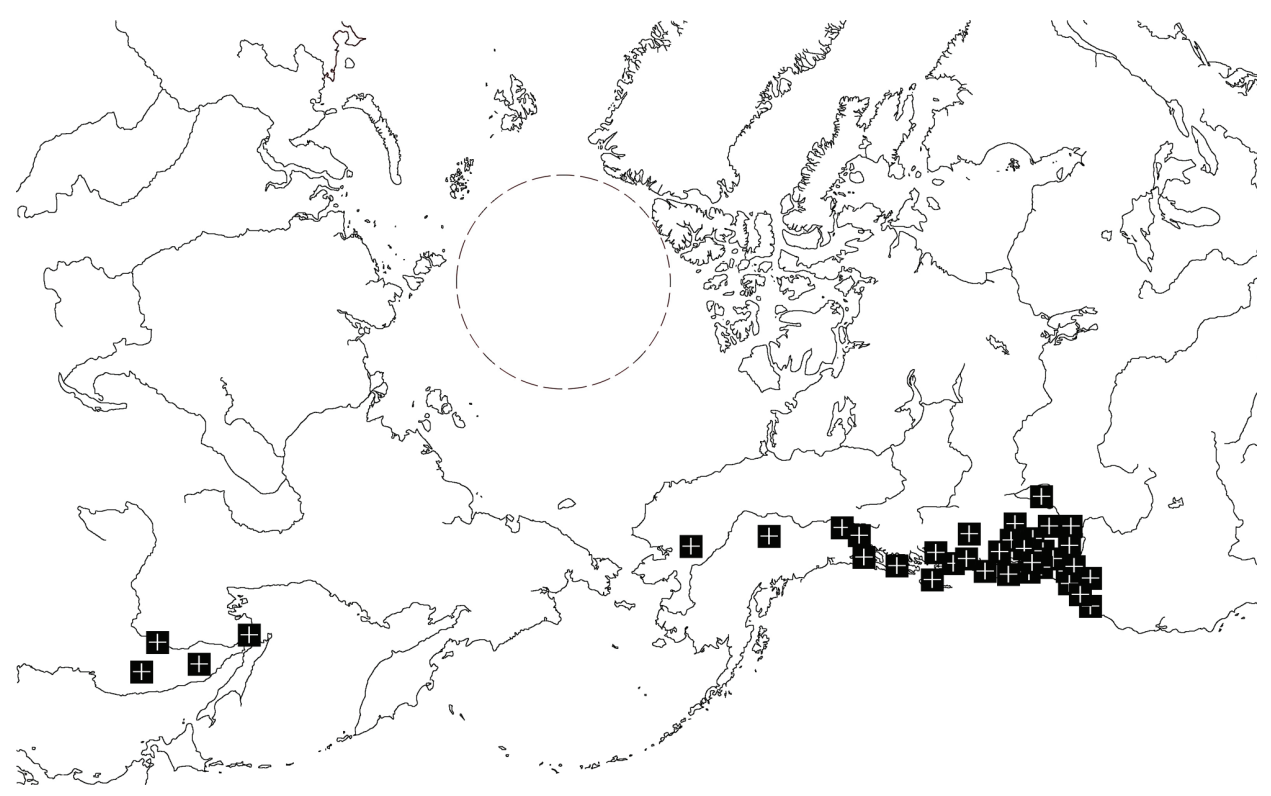

Figure 4. Spread of the motif "Chain of arrows". People shoot arrows, which hit each other's ends, forming a chain (rope, ladder), and climb up this chain to the sky. 


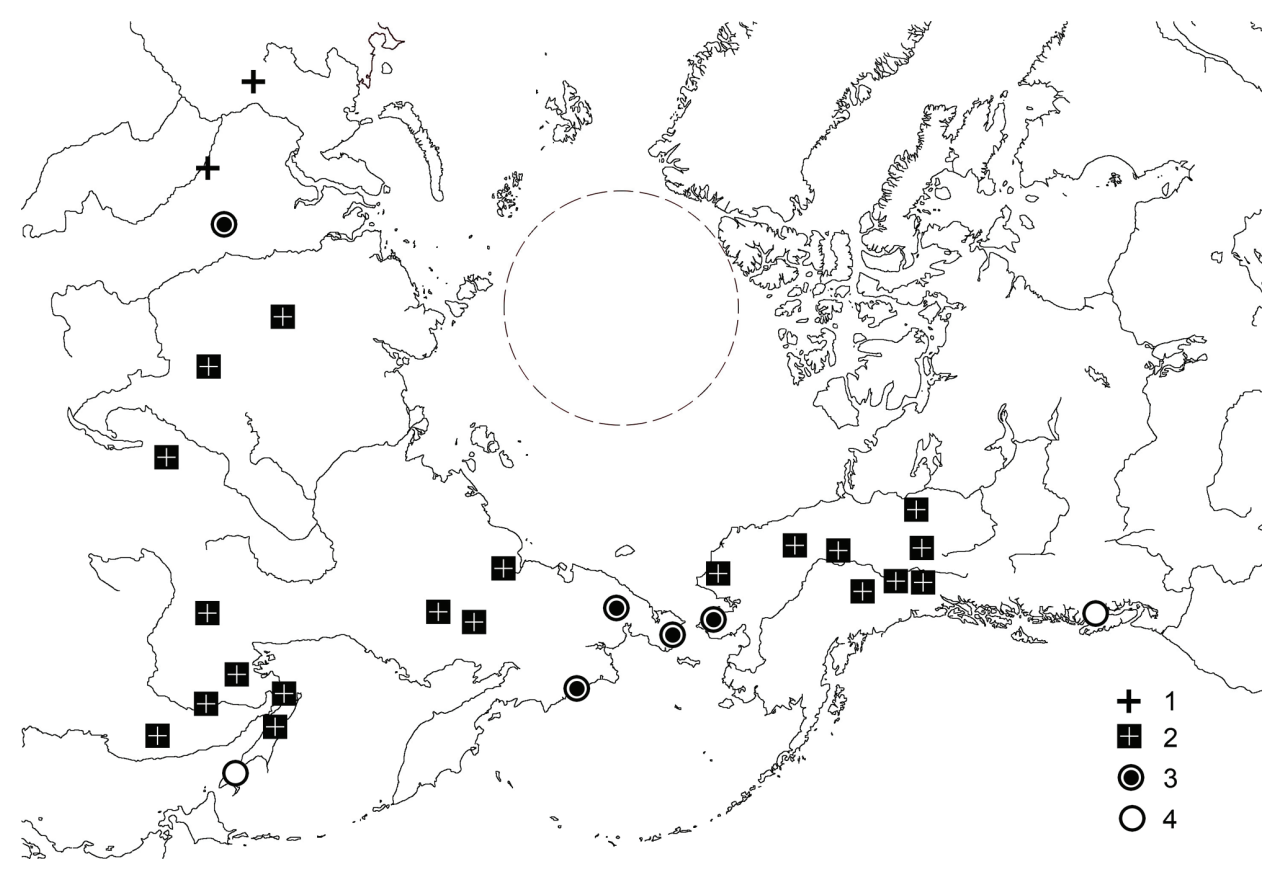

Figure 5. Spread of the motif "Sliding downhill". 1. A person tricks another to slide down a hill, rides behind and kills the other, cutting her with a sledge or skis. 2. A person tricks another to slide down a hill and kills them, putting sharp poles, knives, etc., on the way. 3. Being thoughtless or provoked by another, a person rides down a hill and falls into the water. 4. Provoked by another, a person rides down a hill and falls into a precipice.

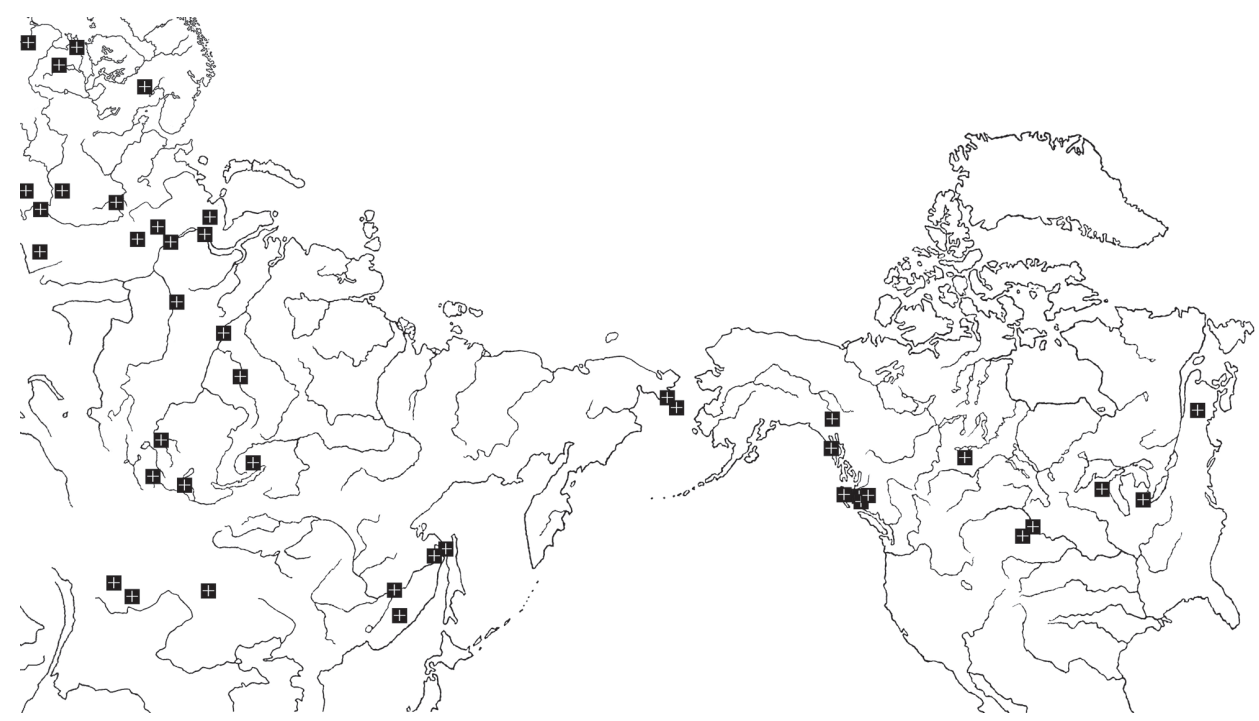

Figure 6. Spread of the motif "Thrown whetstone turns into mountain". Pursued by a dangerous being, a person throws objects that turn into mighty obstacles on the way of the pursuer. One of the objects is a whetstone, which turns into a mountain. 


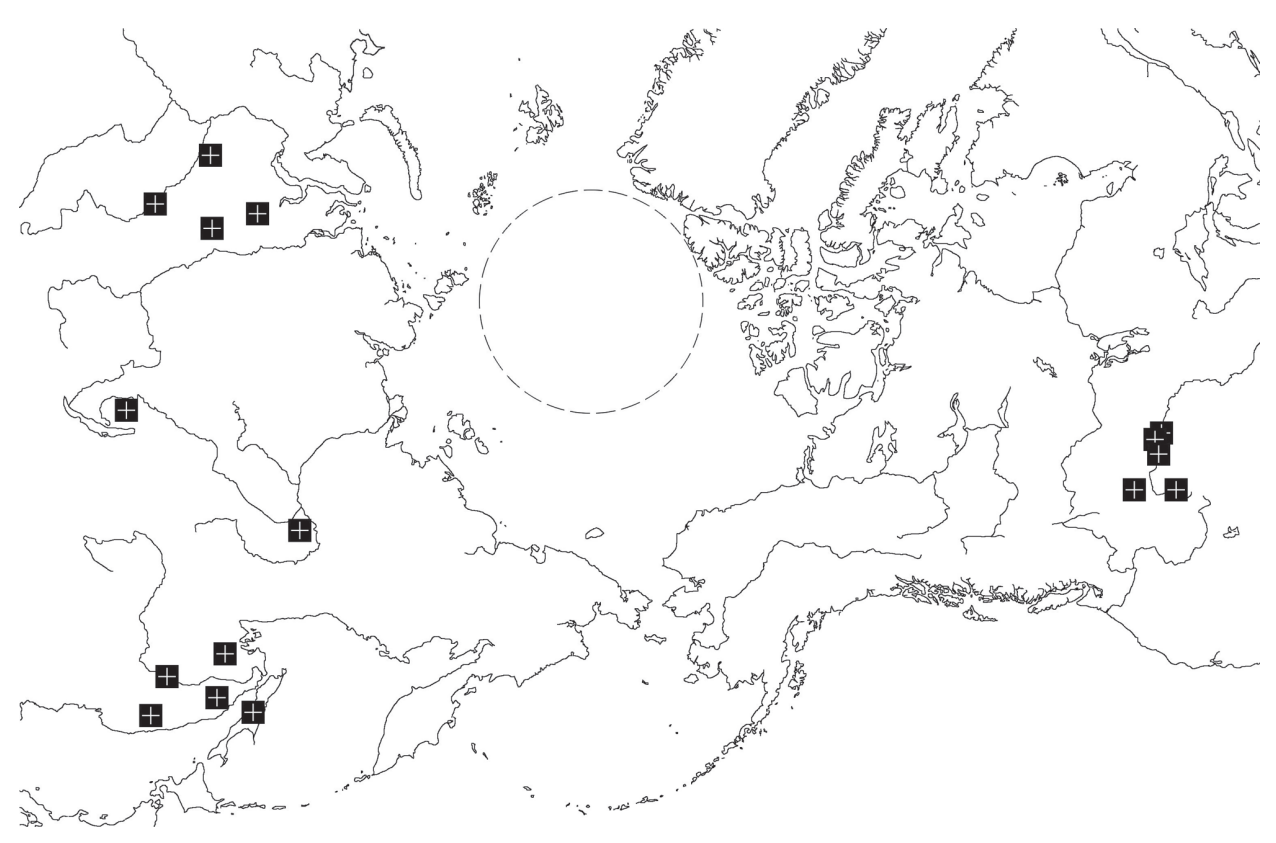

Figure 7. Spread of the motif "Two sisters-in-law, the girl and the frog". One brother marries a girl, another a frog or a toad, or one man takes two wives, a woman and a frog. Both wives have to pass a test. The values of the girl are highly assessed; the frog's poor qualities are revealed.

Some of these motifs have a continuous Siberian-North American spread but others are absent across Asian northeast and American northwest, which excludes their slow diffusion across the Bering Strait during the last millennia. In some of the Northern Eurasian texts, the concentration of motifs that have American parallels is so high that such narratives would not look alien in British Columbia or even Montana.

Narratives described in this article have some vague parallels not only in America but also to the west of the Urals. The heroine's brothers, with whom she parted during her journey to the house of her husband (among the Komi and Sami), or the heroine's sister who lives in the sky and helps her (among the Mordvinians, with more remote parallels among the Mari) remind of the heroin's siblings in Siberian versions. To the west of the Urals, these motifs may have been brought by the Finno-Ugrians, although an earlier time of their westward spread is also feasible. It seems that possible Siberian parallels in the European versions have been obliterated by the motifs that are typical of "international" fairy tales. In the European versions, the latter motifs predominate. 


\section{REVIEW OF THE STORIES ABOUT THE TRAVELLING GIRL}

Below follows a review of some typical texts about the travelling girl and her helpful siblings.

Orochs. During a game, seven brothers hurt a squirrel. The squirrel promises revenge. Brothers hide their sister under the hearth, putting a bag with blood above her. They shoot arrows into the sky that hit each other and form a ladder. Brothers climb it and disappear into the sky. An old shoe tells the squirrels where the girl is hidden. The squirrels poke the hearth, see the blood, decide that the girl is killed, and go away. The girl sets off in search of her brothers and comes to a frog. The frog takes her clothes off and the girl hides inside a stick. Two men come, the older one sits down near the frog, the younger one near the stick, whittles it, blood appears. When he comes again to pick up his forgotten knife he finds the girl instead of the stick. Both men bring their wives home. Being asked to show their kinfolk, the frog brings other frogs, and the father-in-law drives her out. The girl calls her brothers, they descend to the earth, give their sister good garments and return to the sky (Margaritov 1888: 29, another variant in Arsenyev 1995: 122-125).

Variants recorded among the Udeghe (Lebedeva et al. 1998: 225-235, 474476, No. 31, 107), Uilta (Voskoboinikov \& Menovschikov 1951: 373-376), Nanai (Khodzher 2011: 67-77) and Neghidals (Tsintsius 1982: 135-139, No. 25) are similar to the Oroch versions in all major episodes, although the Uilta and the Neghidal texts lack the initial part about a conflict with cannibal squirrels. Some variants contain very detailed descriptions of the competition between the girl and the frog in the house of their father-in-law.

Sakha (Yakuts). Two sisters come across a stone that looks like a person, bring it home and put it into a cradle. The stone turns into a baby. Coming home, the sisters find roasted fish. The younger one turns into a piece of bark and remains home. She sees how the baby extracts fish from his mouth, roasts it, promises to devour the sisters and returns into his cradle. Sisters put a hot pot over the baby and run away. An old woman stretches her leg across the river and the girls cross the river by this bridge. When the demon steps on the old woman's leg, she takes it away and he drowns. The sisters come to a female monster who has one leg and one arm and who imprisons them in a chamber. The younger sister turns into a needle and gets out through a crack in the chamber's wall. The elder one inserts her head into the same crack but is stuck. The younger one pulls the head, tears it off and takes it with her. The head begins to weep when the younger sister attempts to abandon it at a larch or at a birch but is satisfied with being put in a tree that was struck by lightning. The girl comes 
to a house of silver where a female frog lives. The frog asks the girl to make clothes for her husband and hides her from him. The husband understands that the frog could not have done such perfect work, finds the girl and marries her, asks both wives to bring presents from their kinfolk. The frog brings leeches and worms. The girl comes to the tree where she had abandoned her sister's head. She finds her sister intact and alive, living in a nice house and having plenty of cattle. Her husband is Thunder and he gives some cattle to his sister-in-law. The girl's husband kills the worms and leeches brought by the frog and asks the frog to spend a night on the roof of the house. The frog is frozen to death (Vitashevski 1912: 459-465).

The Evenk text from Karama village (Cis-Baikal region) is basically similar to the Sakha version but with a magic flight instead of the leg-bridge episode. Pursued by a monster, the elder sister throws a handkerchief (it turns into a sea) and a comb (a thicket). Then she throws a whetstone but it falls in front of the sisters and becomes a mountain. The younger sister turns into a hair, finds a small hole and comes out from the other side of the mountain. The elder girl becomes an ant, crawls into the hole and gets stuck. The monster swallows the lower part of her body and the younger sister drags out the upper part. Thunder is not mentioned as the husband of the elder sister and it is only said that the heroine got many reindeer from her sister (Titov 1936: 179-181, No. 9-10).

All versions recorded across Western Siberia combine "Travelling girl and her helpful siblings" with the story in which a woman is devoured by a witch but her two daughters escape. Corresponding tales are recorded among the Sym Evenki (Lukina 2004: 75-77, No. 3.18; Vasilevich 1936: 22-24, No. 21, 22), Kets (Kryukova 2013: 202-213), Nganasans (Porotova 1980: 13-19), Northern and Southern Selkups (Pukhnachev 1966: 20-24; Tuchkova 2004: 208-209), Eastern and Northern Khanty (Baulo 2005: 236-239, No. 1; Koptelov 1950: 175-180; Lukina 1990: 101-104, No. 28; Nikolaeva 1999: 133-137, No. 1), Northern Mansi (Kupriyanova 1960: 109-112; Kuzakova 1994: 110-112; Lukina 1990: 334-336, No. 128; Rombandeeva 2005: 289-301, No. 41) and Tundra Nenets (Golovnev 2004: 248-251; Lehtisalo 1947: 147-165, No. 51; Neniang 1997: 61-64).

The lack of space does not permit me to describe two dozen texts; therefore, I shortly retell only three sample versions. The Selkup versions are probably the least detailed, while the Ket and Mansi ones are the richest.

Kets (Kureika River, recorded by Andrei Dul'zon). Hun has a little boy and two girls older than the boy, Kolbassam has her own children. Hun and Kolbassam go to cut the grass, Kolbassam sticks a sharp bone into Hun's ear and brings the body home, covering it with grass. Hun's children notice their mother's braids. They hear Kolbassam say that the next day her children will eat small 
eyes, and she will eat big ones. The boy closes the smoke hole with a cloth full of holes, so that Kolbassam thinks it is still a starry night. The children ask house objects not to betray them if Kolbassam comes and asks where Hun's children went. Kolbassam asks the ladle and the frame of the hearth where the children are. They respond that they were well fed, do not speak. The glue jar betrays the children. Kolbassam sets out in pursuit. A hare, a fox, a wolf, and a bear carry the children on their backs; they are tired. The sisters leave their little brother in a bear's den and reach the river. Their grandmother's tent stands on the other side. The grandmother tells the birch bark to carry the girls across the river and to drown Kolbassam. She tells her granddaughters that two breastbones lie near the ice hole, one with burbot liver and another with marrow; the burbot liver should not be touched. The younger sister does not listen and the devil carries her off. The elder sister (now she is named Hun like her mother) leaves her grandmother. A new Kolbassam jumps out of the stump, suggests searching for lice, puts a sharp bone into Hun's ear, takes her skis. An eagle pulls the bone out, Hun revives, quickly catches up with Kolbassam and takes her skis back. Hun and Kolbassam meet two men, one is the son-prince of the old man Yryt and he marries Kolbassam. Another is the son of an old woman and he marries Hun. The old woman asks Hun to sew a good fell for skies. Hun goes to her brother for glue, glues strong skies, her husband goes to hunt and brings many deer. Kolbassam takes the resin from the "larch uncle", her skies fall apart, the son-prince of the old man Yryt does not get anything. Hun goes to her brother; he asks her husband to put the larch in his house. Her brother's children are bear cubs; they start climbing the larch. Kolbassam brings children of her own brother, they are young pikes, young perches and ides; the old man Yryt accidentally swallows them with water. Kolbassam is killed by thunder. Hun's brother descends from the larch; they begin to live together (Kryukova 2013: 202-213).

Northern Mansi (Khoshlog village). Mosne and Porne live together, each has a daughter and a son. Porne suggests that Mosne slide downhill on wooden skis, slides behind her and crushes her with her iron skis. Mosne's daughter hears how Porne tells her children that they will eat eyes and ears of Mosne's children. Mosne (now the daughter acquires her mother's name) takes her small brother and runs away, throwing a comb (thicket), a flint (flame up to the sky), and a whetstone (mountain). Porne falls behind. Mosne's brother sinks into the ground. Mosne comes to the lake where Porne (i.e. the daughter of the former Porne) invites her to swim, puts on her clothes and gives clothes of bark to her. Mosne forces her to re-exchange the clothes. The son of Toyton-Toyka and the son of Usyn-Otyr-Toyka shoot arrows, Porne grabs the arrow of the son of Toyton-Toyka and marries him. Mosne marries Usyn-Otyr-Toyka's son. She 
goes to the place where her brother disappeared and finds a house. The hostess orders the dogs to lick ice from the guest's feet. Mosne's brother is alive and married but blind in one eye: when he was sinking into the ground, Mosne tried to hold him and accidentally poked his eye. He gives Mosne many reindeer. At home she says that she got an iron chain to encircle the town of her father-inlaw, a copper pot, and a white reindeer. Porne says that she was given a bast rope, half of a clay pot, clothes of bark, and that they harnessed a crucian and a roach. The roach and the crucian go into the ice-hole, the sledges stop, the bast rope breaks, and it is impossible to go far in half of the pot. Mosne's small son says that his uncle's arrow bounces off with a ring, his grandfather's arrow with a thud. Mosne's father-in-law is hurt, goes to war with her brother. Porne suggests removing the sun and the moon from the sky. Mosne attaches luminaries to her sledge, so it becomes dark. After this the father-in-law says he was joking and Mosne puts the luminaries back to the sky (Rombandeeva 2005: 289-301, No. 41).

Tundra Nenets (Gydan Peninsula). Parne and Nenei-ne ("true woman") go to tear grass for insoles. Parne scratches Nenei-ne's face, thrusts her head into the lake and kills her. The victim's daughter sees her mother's earrings in the grass and hears how Parne promises her children to feed them meat of Nenei-ne's children. The girl takes her brother and flees. She throws behind her a board to cut skins (a wooden mountain appears), an iron scraper (an iron mountain), and a flint (an iron ridge). The children ask an old woman to ferry them across the river, praise her face and posture, so that she tells her son to transport them. Parne scolds the old woman's appearance, the old woman's son upsets the boat and Parne sinks. The old woman sends the children out of her house in a boat, and orders them not to look back. The boy disobeys, and branches rip him in half. He (or rather his upper half) asks his sister not to leave him under the boat, near the birch, in the willow, near the larch, explaining that people will come and it will be noisy. He agrees to be left on a sandy hill. The girl's foot falls, she sees seven Parne girls in the hole, runs away; one of the girls catches her and scratches her face. They walk together and meet two men. Parne sits down near the owner of white reindeer, the girl near the owner of black reindeer. After a while, both wives must go home and bring gifts for their husbands. Parne rides to a hole in the ground, returns from the land of seven Parne with a herd of mice. The girl finds her brother alive, he gives her new clothes and reindeer. Parne's husband is furious with her mice, the girl's husband is happy with the gifts. Parne is thrown into the fire, mosquitoes appear from the ashes (Golovnev 2004: 248-251).

The Taimyr version recorded by Kazimir Labanauskas (Neniang 1997: 6164 ) ends with the story of the "thrown-away" boy that has parallels in Siberia 
(the Buryats, Enets, Southern Mansi, Northern and Southern Selkups, Orochs) and considerably more in North America. The heroine gives birth to a boy, the witch replaces him with a half-a-dog and hides under a heap of chips. A birch grows from under the chips, the witch throws it into a lake and says that "water is his father, water is his mother". The woman is abandoned and raises halfa-dog while her son lives in the water. Half-a-dog catches the boy, calls the woman for help. Pieces of ice begin to move from the river towards the house but the boy stops them, advising to throw half-a-dog into the water.

As mentioned above, the European versions contain episodes that are typical of the Eurasian fairy tales and are considerably more different from the Siberian ones than the Siberian versions are from each other.

Komi. Three brothers and a sister bury their mother under the stove, father under the millstone, and go to seek fortune. The elder brother climbs on a silver birch to break silver branches. His sister warns him that he will get stuck and he does stay on the birch. The same happens with the middle and younger brothers (golden birch and pearl birch). The girl comes to the house of the prince, hides under an overturned vat, sings a song about her brothers. The elder and middle sons of the prince cannot find the singer, the younger one finds her. The girl says that she heard him promise to save her brothers. They come to the silver birch, the prince's son waves his sleeve and the boy descends. The same happens with the brothers on gold and silver birches. The girl marries the youngest son of the prince (Plesovski 1975: 15-17).

Mordvinians. After having been in the forest for three years, the old man bends down to drink, Vediava grabs his beard. She refuses to take a stallion, barn, or mill, and demands to give her what the old man does not know he has at home. He comes home and meets his three-year-old daughter. The girl grows up and has one silver tooth. When she goes to Vediava, she covers her tooth with wax. On her way she meets ugly old men, but they do not recognize her. Seeing ugly old women, the girl laughs, the wax falls off, the old men and women run after her. The girl throws a maple comb (maple forest), a whetstone (mountain), and a brush (turns into a tree). The tree grows, the girl climbs it, the old men and women begin to gnaw the trunk. The girl asks her sister to let down a thread from the sky. The sister replies that first she must plow the field, sow hemp, etc. (all kinds of works with hemp enumerated). Finally, she lets down the thread, her sister climbs up to the sky, the tree collapses, the old men and women begin to gnaw each other. In the sky, the sister hides her; the sister's husband is a bear, she sends the bear to carry a chest to her parents. The bear leaves the chest in the yard, the parents find their daughter in it (Yevsevyev 1964: 150-154, No. 18; a similar variant in Paasonen 1941: 282-291). 
Eastern Sami (Kildin dialect, Yokanga River). After the death of their parents, three sons and a daughter are left alone. They go along the river by boat. The girl sees a gilded tree on the shore, asks to stop. The eldest brother says that he will bring a branch himself, goes ashore, and stays there. The episode repeats, all three brothers stay in different places on the shore. The girl goes ashore, follows a rolling spindle, comes to an old man and an old woman. They say that the bride has come to their youngest son. Two elder sons are married, the youngest one marries the girl. The elder daughters-in-law are daughters of a spider. They shut the girl's mouth with a button, push the button with a spindle, make fire under the barn. The old man saves the girl but the elder daughters-in-law say that she ate her own baby. The episode repeats two more times. Two geese and a swan descend, become two boys and a girl, mother and father recognize their children. The spider daughters and their children are told to jump over the fire; they fall into it and burn (Kert 1961: 175-179, No. 44).

\section{SIBERIAN FOLKLORE AND THE ATU SYSTEM}

The stories described above have been recorded across Northern Asia, from Western Siberia to the Far East. They share as many common episodes as European, Near Eastern and Indian sets of texts that belong to particular tale types of the ATU index. "The Travelling Girl" is but one of many tales widespread across Northern as well as Central Asia, which have not found their place in the ATU system (for another example see Berezkin \& Duvakin 2016).

The Northern and Central Asian folklore is rich. The very number of narrative episodes and ideas connected with the worldview, registered in Northern Asia (up to the southern border of Russia) and described in our electronic catalogue, is bigger than in the South Asian traditions. For ten of the best-known Siberian traditions, these numbers are as follows: Buryat - 347, Khakas - 260, Tuvinians of Tuva - 257, Southern Altai - 253, Nanai - 232, Mansi - 226, Chukchi - 219, Central Yakut - 220, Western Tungus - 192, Tundra Nenets - 188. For ten of the best known South Asian traditions the corresponding numbers are smaller: Hindi-speaking people of Uttar Pradesh and adjacent states - 248, Sinhalese 201, Punjabi - 169, Bengali - 162, Santali - 149, Mundari with related Northern Munda groups - 142, Baiga - 128, Marathi - 118, Tamil - 118, Kashmiri - 118.

The difference is proportionally bigger than between the Siberian and the Atlantic European traditions which have been very well described by folklorists. The corresponding numbers for the latter are: French - 431, Portuguese - 367, Norwegian - 294, Irish - 282, Basque - 219, Breton - 169. As we gather additional folklore materials, all these numbers increase but the proportion between 
the regions does not change. However, unlike the South Asian and European materials, the Siberian narratives have never been systematically described. The existence of similar elements in texts recorded between the Urals and the Pacific never attracted serious attention from researchers and, as far as I know, there have been no plans to create a regional tale type index. This is despite the fact that such indexes (certainly of very different quality) are available for most of the regions of the Old World.

What can be the reason for such a neglect? To answer this question, we must return to the ATU index mentioned at the beginning of this paper.

The tale type index created by Antti Aarne and later modified and expanded by Stith Thompson is the universally recognized cornerstone of folklore studies. For a long time, it was known as AT (Aarne and Thompson 1961) and only became ATU in the twenty-first century (Uther 2004). Thompson's preferences, interests and knowledge had a crucial influence on the further development of the entire discipline. The Folktale (Thompson 1946) is the key source for understanding Thompson's views. In this book, the following assumptions are most clearly expressed.

Firstly, the system of tale types as discrete and clearly recognized units is peculiar for the territory from Morocco and Ireland to India, while in Southeast Asia, Siberia, and sub-Saharan Africa we have but random and late loans. The tale type system described in AT is a product of civilized societies ("Western civilization"). Siberia was practically ignored by Thompson and was mentioned by him only once; the same goes for Central Asia.

Secondly, there are no significant areal differences inside this system; therefore, it can be analyzed as a whole. The folklore of early civilizations of the Old World has been lost, but the fragments that are preserved in written sources let us suggest that it was not very different from what was recorded in Europe after 1800 .

Thirdly, the folklore of the American Indians (which Thompson knew perfectly well and interpreted as an example of cultural phenomena typical of primitive society) is impossible to study together with the folklore of the "Western civilization". The two traditions correspond to different types of society.

Hans-Jörg Uther tried to correct the faults of the AT index and used more data from non-European traditions (Uther 2004 (1): 7-8). However, the main limitations of the AT remained. The list of selected tale types was not expanded and continued to be based on European data. Only very few original sources on Central and East Asia were added. Most of the Siberian folklore was left beyond the scope of the "international" system. In other words, the conceptual pattern generated by Thompson was not replaced with a new one but reproduced once again. 
The creation of a global and not of a Western Eurasian system of recording and classifying of traditional narratives is impossible without keeping in mind the basic purpose of such work. The elaboration of the typology itself is but a technical task. When creating his index of elementary motifs (Thompson 1932-1936), in addition to the tale type index, Thompson tried to draw data from the entire world into a common framework. However, he did it with a declared purpose of excluding any regional specificity and thus any historical problematic of the research. Being a philologist who began his career with the study of English literature, Thompson could not have done otherwise. He knew little about prehistory and had no interest in it. Our purpose is different, namely to use folklore data for the study of the past; in particular, to reveal migrations, cultural contacts and interaction spheres and ultimately sets of narrative episodes and images that existed in different regions and epochs. Keeping this purpose in mind, we need an integration of the world folklore into a unified system that would emphasize regional differences and not typological similarities.

\section{ACKNOWLEDGEMENTS}

Research for this article was supported by the Russian Science Foundation, grant no. 18-18-00361.

\section{REFERENCES}

Aarne, Antti \& Thompson, Stith 1961. The Types of the Folktale. Helsinki: Academia Scientiarum Fennica.

Anderson, Jake 2004. From Alaska to Greenland: A Comparison of the Arctic Small Tool and Thule Traditions. Totem: The University of Western Ontario Journal of Anthropology, Vol. 12, No. 1, pp. 6-15. Available at https://ir.lib.uwo.ca/totem/ vol12/iss1/2/, last accessed on 22 February 2019.

Arsenyev 1995 = Arsen'ev, Vladimir. Iz nauchnogo naslediia V.K. Arsen'eva. [From the Scientific Heritage of V. K. Arsenyev.] Kraevedcheskii biulleten', Vol. 1, pp. 111-131. Available at http://peb.libsakh.ru:3783/reader/bookView. html?params=UmVzb3VyY2UtNjIy/MDAwMDAyNTY4, last accessed on 19 February 2019.

Baulo, Arkadii (ed.) 2005. Synskie Khanty. [The Syn River Khanty.] Novosibirsk: Izd-vo Instituta arkheologii i etnografii SO RAN.

Berezkin, Yuri 2015. Folklore and Mythology Catalogue: Its Lay-Out and Potential for Research. In: Frog \& Karina Lukin (eds.) Between Text and Practice: Mythology, Religion and Research. The Retrospective Methods Network Newsletter 10. A special issue of RMN Newsletter. Helsinki: University of Helsinki, pp. 58-70. 
Available at http://www.academia.edu/14481230, last accessed on 19 February 2019.

Berezkin, Yuri 2019. Athabaskan - Siberian Folklore Links: In Search of Na-Dene Origins. Folklore, Vol. 130, No. 1, pp. 31-47.

Berezkin, Yuri \& Duvakin, Evgeny 2016. The Captive Khan and the Clever Daughterin-Law. Folklore: Electronic Journal of Folklore, Vol. 64, pp. 33-56. http://dx.doi. org/10.7592/FEJF2016.64.khan.

Berezkin, Yuri \& Duvakin, Evgeny n.d. Tematicheskaia klassifikatsiia i raspredelenie fol'klorno-mifologicheskikh motivov po arealam. Analiticheskii katalog. [The Electronic Analytical Catalogue of Folklore-Mythological Motifs: Thematic Classification and Areal Distribution]. Available at http://www.ruthenia.ru/ folklore/berezkin, last accessed on 19 February 2019.

Dumond, Don E. 2005. A Naknek Chronicle: Ten Thousand Years in a Land of Lakes and Rivers and Mountains of Fire. King Salmon, Alaska: U.S. Dept. of the Interior, National Park Service, Katmai National Park \& Preserve.

Golovnev, Andrei 2004. Kochevniki tundry: nentsy i ikh fol'klor. [Nomads of Tundra: The Nenets People and Their Folklore.] Yekaterinburg: UrO RAN.

Kert, Georgi 1961. Obraztsy saamskoi rechi. Materialy po iazyku i fol'kloru saamov Kol'skogo poluostrova (kil'dinskii i iokan'gskii dialekty). [Samples of Sami Talk.] Moscow \& Leningrad: Izd-vo Akademii nauk SSSR.

Khodzher, Anna 2011. Stekliannaia veranda. Taokhama giaygi. [The Glass Verandah.] Khabarovsk: Khabarovskii kraevoi muzei im. N.I. Grodekova.

Koptelov, Afanasi 1950. Skazki narodov Sibiri. [Folktales of Siberian Peoples.] Novosibirsk: Novosibirskoe oblastnoe gosudarstvennoe izdatel'stvo.

Kryukova 2013 = Kriukova, Elena A. Khun's kolbassam zhili: ketskii tekst / Hun and Kolbassam Lived: A Ket Text. In: A. Filchenko (ed.) Annotirovannye fol'klornye $i$ bytovye teksty obsko-eniseiskogo iazykovogo areala / Annotated Folk and Daily Prose Texts in the Languages of Ob-Yenissei Linguistic Area, Vol. 3. Tomsk: Tomsk State Pedagogical University, pp. 202-294.

Kupriyanova 1960 = Kupriianova, Zinaida. Nenetskii fol'klor. Uchebnoe posobie dlia pedagogicheskikh uchilishch. [Nenets Folklore.] Leningrad: Gosudarstvennoe uchebno-pedagogicheskoe Izd-vo ministerstva prosveshcheniia RSFSR.

Kuzakova, Evdokiia 1994. Folklor mansi. [Mansi Folklore.] Moscow: Institut etnologii i antropologii im. N.N. Miklukho-Maklaia RAN.

Lebedeva, Elena \& Khasanova, Marina \& Kialundziuga, Valentina \& Simonov, M. (comps.) 1998. Fol'klor udegeitsev: Nimanku, telungu, ekhe. [Udeghe Folklore.] Novosibirsk: Nauka.

Lehtisalo, Toivo 1947. Juraksamojedische Volksdichtung. Helsinki: Suomalais-Ugrilainen Seura.

Lukina, Nadezhda 1990. Mify, predaniia, skazki khantov i mansi. [Myths, Legends, Tales of the Khanty and Mansi.] Moscow: Nauka.

Lukina, Nadezhda (ed.) 2004. Skazaniia zemli Tomskoi: khrestomatiia. [Tales of the Land of Tomsk: A Reader.] Tomsk: Izdatel'stvo Tomskogo gosudarstvennogo pedagogicheskogo universiteta.

Margaritov, Vasili1888. Ob orochakh Imperatorskoi Gavani. [On the Orochis of Imperatorskaya Gavan'.] Saint Petersburg: Izdanie obshchestva izucheniia Amurskogo kraia v g. Vladivostoke. 
Neniang, Liubov 1997. Khodiachii um naroda: Skazki, legendy, mify, predaniia, epicheskie pesni, poslovitsy, pogovorki, pover'ia, oberegi, narodnye primety, zagadki taimyrskikh nentsev. [People's Shifting Intelligence: Folktales, Legends, Myths, Traditions, Epic Songs, Proverbs, Sayings, Beliefs, Amulets, Omens, Riddles of Taimyr Nenets.] Krasnoyarsk: Fond severnykh literatur "KhEGLEN".

Nikolaeva, Irina 1999. Ostyak Texts in the Obdorsk Dialect. Wiesbaden: Harrassowitz Verlag.

Paasonen, Heikki 1941. Mordwinische Volksdichtung. Gesammelt von H. Paasonen, herausgegeben und übersetzt von Paavo Ravila. III Band. Helsinki: SuomalaisUgrilainen Seura.

Plesovskii, Fedor 1975. Komi narodnye skazki. [Komi Folktales.] Syktyvkar: Komi knizhnoe izdatel'stvo.

Porotova, Tel'mina (ed.) 1980. Skazki narodov sibirskogo severa. [Folk Tales of the Peoples of the Siberian North.] Vol. 3. Tomsk: Izd-vo Tomskogo universiteta.

Pukhnachev, Vasili 1966. Skazki starogo Tyma. [Folktales of Old Tym.] Novosibirsk: Zapadno-Sibirskoe knizhnoe izdatel'stvo.

Rombandeeva, Evdokiia (comp.) 2005. Mify, skazki, predaniia mansi (vogulov). [Myths, Folktales, Legends of Mansi (Vogul).] Moscow \& Novosibirsk: Nauka.

Thompson, Stith 1932-1936. Motif-Index of Folk Literature. Vol. I-VI. Helsinki: Suomalainen Tiedeakatemia.

Thompson, Stith 1946. The Folktale. New York: The Dryden Press. Available at http:// folkmasa.org/yashpeh/The_Folktale.pdf, last accessed on 22 February 2019.

Titov, Elpidifor 1936. Materialy po ustnomu tvorchestvu evenkov Pribaikal'ia. [Materials on the Oral Creative Work of the Cis-Baikal Tungus.] In: G. Vasilevich (comp.) Sbornik materialov po evenkiiskomu (tungusskomu) fol'kloru. Issue 1. Leningrad: Izdatel'stvo instituta narodov Severa, pp. 162-212. Available at https:// yadi.sk/d/q_ivzGyfHwwVr, last accessed on 22 February 2019.

Tsintsius, Vera 1982. Negidal'skii iazyk: Issledovaniia $i$ materialy. [The Neghidal Language: Studies and Materials.] Leningrad: Nauka. Available at http://altaica. ru/LIBRARY/tungus/negidal.pdf, last accessed on 20 February 2019.

Tuchkova, Natalia (comp.) 2004. Mifologiia sel'kupov. [Selkup Mythology.] Tomsk: Izdatel'stvo Tomskogo Universiteta. Available at https://www.academia. edu/31457383/, last accessed on 20 February 2019.

Uther, Hans-Jörg 2004. The Types of International Folktales: A Classification and Bibliography Based on the System of Antti Aarne and Stith Thompson. Vol. 1-3. Helsinki: Suomalainen Tiedeakatemia.

Vasilevich, Glafira 1936. Materialy po fol'kloru sibirskikh evenkov. [Materials on the Folklore of the Siberian Tungus.] In: G. Vasilevich (comp.) Sbornik materialov po evenkiiskomu (tungusskomu) fol'kloru. Issue 1. Leningrad: Izdatel'stvo instituta narodov Severa, pp. 1-136. Available at https://yadi.sk/d/q_ivzGyfHwwVr, last accessed on 20 February 2019.

Vitashevski, Nikolai 1912. K materialam o iakutskikh skazkakh. [To the Materials on Yakut Folktales.] Zhivaia starina, Year 21, Vol. 2-4, pp. 449-466.

Voskoboinikov, Mikhail \& Menovshchikov, Georgi 1951. Skazki narodov Severa. [Folktales of the Peoples of the North.] Moscow \& Leningrad: Gosudarstvennoe Izdatel'stvo Khudozhestvennoi literatury.

Yevsevyev 1964 = Evsev'ev, Makar. Mordovskie narodnye skazki i zagadki. [Mordovian Folktales and Riddles.] Saransk: Mordovskoe knizhnoe izdatel'stvo. 